\title{
The neurobiological interpretation of the mental functions in the work of Santiago Ramón y Cajal
}

\author{
FRANCISCO LÓPEZ-MUÑOZ* \\ University of Alcalá, Madrid \\ CECILIO ALAMO \\ University of Alcalá, Madrid \\ GABRIEL RUBIO \\ Complutense University, Madrid
}

Cajal (1852-1934) first had contact with the fields of psychiatry and psychology through the experimental study of hypnotism. He interpreted this phenomenon as an aberrant failure of the machinery of the brain. It may be that Cajal's initial interest in the theory of hypnotic suggestion eventually led him to study the biological phenomena related to sleep and dreams, in the neurophysiological explanation of which he disagreed openly with Freud's postulates. Finally, Cajal studied the histophysiological mechanisms of the higher mental functions (thought, intelligence, memory, perception, etc.). He proposed that the pyramidal cells of the cerebral cortex, which he called 'psychic cells', formed the substrate of these functions; he proposed the law of 'avalanche conduction', and he speculated on the possibility of a phenomenon of neuronal plasticity in relation to learning processes. After being awarded the Nobel Prize in 1906, Cajal's interests in psychological aspects began to decline.

Keywords: history of medicine; hypnotism; mental functions; psychiatry; psychology; Santiago Ramón y Cajal; Sigmund Freud; sleep; Spain

\section{Introduction}

Santiago Ramón y Cajal (1852-1934; Fig. 1) did his most intense scientific work around the turn of the nineteenth century, when psychiatry, under the

\footnotetext{
* Address for correspondence: C/ Juan Ignacio Luca de Tena 8, 28027 Madrid, Spain. Email: frlopez@juste.net
} 


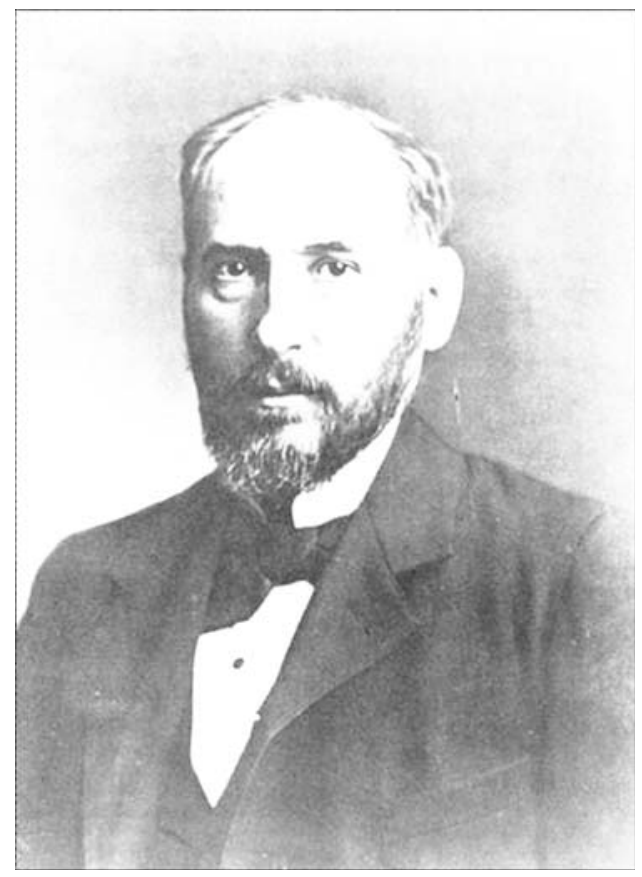

FIG. 1. Santiago Ramón y Cajal in 1899 , aged 47

(source: http://www.redaragon.com/ cultura/ramonycajal)

doctrinal authority of Emil Kraepelin (1856-1926), maintained the somatic character that had been consolidated over the last third of the nineteenth century. It was undoubtedly these scientific influences that assigned mental disorders to alterations in the anatomical substrate, and this led to the hypothesis that the mental processes governing everyday life (thought, consciousness, intelligence, imagination, memory, etc.) must also be located in a particular anatomical substrate. This approach to understanding the psyche and its disorders inevitably linked up with the morphological and neurobiological proposals put forward by Cajal.

However, the origins of Cajal's contacts with the psychiatric and psychological fields lie in a less organicist movement, and one less scientifically important, which at that time was sweeping all before it and which would be the source of the Freudian psychoanalytical trends: hypnotism.

The origin of this movement dated from the mesmerist theories of 'universal magnetic fluid', which was extremely popular outside clinical circles in the Europe of the first half of the nineteenth century. It entered the medical field thanks to the study by the French school in Paris of the problematic condition of hysteria (Gauld, 1992). The application of hypnotism to the study of hysterical paralysis by Jean-Martin Charcot (1825-1893) at the Salpêtrière hospital in Paris laid the foundations for the establishment of psychoanalysis and psychotherapeutic techniques (Ellenberger, 1976). In addition to studying this unpleasant disorder using the semiological criteria that he systematically employed in other pathologies, Charcot decided to apply hypnotic techniques to the analysis of hysteria, describing his results to the Paris Academy of Sciences in 1882: Sur les divers états nerveux déterminés par l'hypnotisation chez les hystériques. He thus adopted the aetiopathogenic hypothesis of autosuggestion in the study of hysteria and gave scientific credibility to hypnosis as a diagnostic tool in psychiatry (Diéguez, Campos and Huertas, 2006). ${ }^{1}$

Although some authors claim that Cajal's research preferences did not include the field of psychiatry/psychology (López-Ibor and Fuentenebro, 2006), this assertion requires some clarification. It is true that publications 
by Cajal dealing specifically with this field amount to no more than $1.7 \%$ of his global scientific output, according to a bibliometric study carried out by our group (López-Muñoz, Carbonell and Boya, 1998) on a total sample of 353 scientific publications. There are only six publications specifically on this subject - or nine if we include the international versions of some of these works, mainly published in German journals, and other texts of a histological nature in which the author dedicates special sections to the topics covered in the present study, such as that of the Croonian Lecture $(1894 a, 1894 b$; see Appendix A). To this output, we should add three manuscripts, finished before Cajal's death but not published, and subsequently lost during the Spanish Civil War (Durán and Alonso, 1983) (Appendix B), and, also on psychiatric/ psychological subjects, four forewords to books (Appendix C). This complete body of works shows that Cajal's interest in psychiatric and/or psychological topics was neither scant nor trivial. Indeed, his written output in this field is even greater than that of some of the most prestigious Spanish clinical doctors of the period, and it has been claimed that 'it is not that Cajal could have been and eminent psychologist - he actually was one' (Elguero, 2004: 16).

In what follows, we shall analyse this scientific output, generated mainly in the period 1890-1910, which we have broken down into three main groups: the experimental study of hypnotism; the hypothetical proposals on the mechanisms of sleep; and the study of the histophysiological mechanisms of higher mental processes. In this regard, it may be that Cajal's initial interest in hypnotic suggestion led him, over time, to the study of biological phenomena related to sleep and dreams, and finally to the attempt to attribute a histological explanation of a biomechanical and physiological nature to the higher mental functions, such as memory, perception and thought itself.

\section{Phenomenon of hypnotic suggestion: Cajal's first approach to the study of brain functionalism}

Psychiatric movements linked to the use of hypnotism rapidly became popular in Spain (González, Cano and Miguel-Tobal, 1995). During his period as Professor of Anatomy in Valencia (1883-87), Cajal carried out scientific research on an area of morbid psychology, which he referred to as the phenomena of suggestion and artificial somnambulism. It was precisely at this time that hypnotism reached its scientific peak, thanks largely to the controversial scientific confrontation that began in 1883 between two French groups: the Charcot school at the Salpêtrière hospital in Paris and the group led by Hippolyte-Marie Bernheim (1837-1919) and Ambroise Auguste Liébault (1823-1904) at the University of Nancy. While the followers of Charcot saw hypnotism as a type of 'induced neurosis' which might serve as an experimental model for the study of hysteria, the disciples of Bernheim and Liébault went back to Braidist principles, attaching greater importance to the phenomenon of suggestion (and its therapeutic application) than to that of hypnotism itself (Diéguez and Diéguez, 2002; Gauld, 1992). 
In his own experiments with hypnosis, Cajal favoured Bernheim's psychotherapeutic conception (Timoner, Nicolau, Gamundí and Rial, 1995; Youssef and Schorer, 1996) rather than the specific experimental focus of the Charcotian trend, ${ }^{2}$ even though he had previously stated that 'we should note that despite three centuries of positive science, the attraction of the magical still runs deep in the human spirit' (Cajal, 1923: 192). Concerning Cajal's initial reservations, we have to bear in mind that during the second half of the nineteenth century the supporters of hypnotism as a scientific medical discipline had to face a considerable number of detractors (including the Catholic Church), who associated it with the popular charlatanism, spiritism and other phenomena of occultism and demonology (Albarracín, 1972). Nevertheless, interest in these metapsychic areas became consolidated, from the point of view of systematic scientific study, around many important scientific figures of the era, including Cajal. $^{3}$

Youssef and Schorer (1996) suggest that it may have been the psychiatrist Luis Simarro (1851-1921) who introduced Cajal to hypnotic techniques. After 7 years of training in Paris, Simarro settled in Madrid in 1887, the year after Bernheim published his famous work De la suggestion et de ses applications à la thérapeutique (1886). In the same year, Cajal was assigned to the Professorial Appointments Committee for Descriptive Anatomy, and he had to move to Madrid. This enabled him to visit a variety of institutions carrying out micrographic research, including a private laboratory run by Simarro and devoted to the histopathological study of disorders of the nervous system where the psychiatrist was applying all the latest techniques developed abroad. ${ }^{4}$ It has been suggested by Youssef and Schorer (1996) that during this visit Simarro may have brought his colleague up to date with the latest French approaches to hypnosis.

Cajal felt that some manifestations of 'this new science, the direct heir of medieval sorcery' corresponded to anomalies of brain dynamics (Cajal, 1923: 192). Based on this notion, he set about a methodical scientific analysis, and to this end he founded, together with some colleagues from the Agricultural Club discussion circle, a Committee for Psychological Research, ${ }^{5}$ with its headquarters in his own home: 'My home was witness to a procession of strange kinds of hysterics, neurasthenics, maniacs and even accredited spiritual mediums' (p. 193).

Among the studies, Cajal highlights the experiments in hypnosis carried out on healthy subjects (physicians and lawyers, among other volunteers) and, above all, its therapeutic application. Among the achievements in terms of therapy, several stand out:

the radical transformation in the emotional state of the patients (an almost instantaneous change from sadness to joy); the restoration of appetite in extremely emaciated hysteroepileptics; the cure, through simply giving an order, of a range of chronic paralyses of an hysterical nature; the sudden 
cessation of attacks of hysteria with loss of consciousness; the eradication of memories of painful and harrowing events; the complete removal of labour pains in healthy women; indeed, surgical anaesthesia, etc. (p. 193)

He wrote a scientific article, Dolores de parto considerablemente atenuados por la sugestión hipnótica, which was published during his time in Barcelona (Cajal, 1889). Durán and Alonso (1960) have suggested that the subject of this article was his own wife, Silveria Fañanás, and that Cajal put his experience in hypnosis into practice to reduce the pain during the birth of their sixth child. ${ }^{6}$

The method used was as follows: during the last ten days before birth, hypnotic suggestion was practised with the patient, with messages referring to a speedy birth with light and easily bearable pains, despite 'awareness of the stronger pains'. As to the success of the venture, Cajal remarks that:

two phenomena attracted our attention: the extreme rapidity of the birth and the considerable reduction of the pain, the subjective manifestation of the contractions ... We can consider the second phenomenon, absence of pain, as being truly brought about by hypnotism. (Cajal, 1889: 486)

This was possibly the first time that the use of hypnotism in reducing labour pain had been documented in a scientific publication. ${ }^{7}$ Nevertheless, Youssef and Schorer (1996) confirm that Cajal's contribution to the therapeutic application of hypnotism made no scientific impression whatsoever, since the journal in which it was published (Gaceta Médica Catalana) was not distributed internationally, and his discovery was not mentioned by any significant author in this field in subsequent reviews, in relation to either hypnosis (Bernheim in his successive studies, Pierre Janet, Morton Prince, Luis Wolberg, Milton Ericson), or gynaecology (Joseph DeLee).

Once all the data of scientific interest to Cajal had been collected, the Committee for Psychological Research was wound up. The number of case reports collected by Cajal and his Committee on hypnosis and suggestion in wakeful states, among volunteers as well as mental and somatic patients, was very large. Nevertheless, Cajal never managed to publish the data generated by this research, although they may have formed part of a manuscript entitled Ensayos sobre el hipnotismo, el espiritismo y la metapsíquica (Essays on hypnotism, spiritism and metapsychic). From his correspondence with the publisher Ramón Pueyo, it appears that Cajal would have had these essays printed if he had not died before it could be done. By great misfortune, the unpublished originals were subsequently lost during the course of the Spanish Civil War.

The great attraction of this 'new science' for Cajal doubtless derives from its close links with the study of the brain. Thus, not only did he concern himself with gathering extensive case records of his own, but he also studied the findings of many foreign researchers. From his perspective, hypnotic suggestion was an aberrant failure of an almost perfect machine, the brain. As a conclusion to this research activity, Cajal admitted that: 
the experiments in suggestion caused me both amazement and disillusionment: amazement to see the reality of phenomena of cerebral automatism that had previously been considered as nothing more than the theatrical trickery of circus mesmerizers; and painful disappointment to see that the highly esteemed human brain, the masterpiece of creation, suffers from the enormous defect of suggestibility. (Cajal, 1923: 194)

However, despite closing down the Committee, Cajal's experiments and interest in hypnosis lasted for the rest of his life, and he even returned to these techniques during his Madrid period.

\section{Cajal and the analysis of neurobiological mechanisms in higher mental processes}

Cajal maintained his interest in formulating psychological hypotheses to explain the workings of the mind throughout his life. On the subject of his interest in psychological fields, he wrote in his memoirs, Recuerdos de mi vida: 'The problem attracted us irresistibly. We realized the crucial importance, for the construction of a rational psychology, of precise knowledge of the brain's texture' (Cajal, 1923: 189); and he concluded that 'knowledge of the brain means knowledge of the material channels of thought and volition' (p. 189). Elsewhere in the same book he says:

in the fashion of the entomologist hunting for butterflies with magnificent colours, my attention, in the orchard of the grey matter, was drawn to delicate and elegant cells, the mysterious butterflies of the soul, the beating of whose wings might one day, who knows, reveal the secret of mental life. (p. 222; original italics)

\section{On the anatomical location of the higher mental functions}

Cajal's first approaches to the study of the histological mechanisms of the mental functions took place during his time as Professor of Normal Histology and Pathological Anatomy at the University of Barcelona (1887-92). Towards the end of this period, he gave a series of lectures at the Academy and Laboratory of Medical Sciences of Catalonia, which were later published as El nuevo concepto de la histología de los centros nerviosos (Cajal, 1892). ${ }^{8}$ In this work, Cajal refers to a topic hotly debated around the turn of the century, and one that linked up with the reductionist ideas in science: the anatomical (or histological in this case) location of the higher mental functions. For Cajal and for many other neuroscientists (Køppe, 1983), from the purely mechanistic standpoint, the appropriate place to locate these functions is the cerebral cortex, so that each individual cell in the peripheral nervous system would have a specific representation in a cortical cell. Likewise, in the same publication Cajal (1892) proposes the pyramidal cells of the cerebral cortex as the ideal candidates for forming the substrate of the higher mental functions (thought, perception, 
memory). Indeed, he considers them among the most important structures of the human nervous system, and refers to them as 'psychic cells'.

Psychological interpretations of the histological findings: the law of avalanche conduction and the inference of the neuronal plasticity phenomenon

In 1894 Cajal was invited by Sir Michael Foster (1833-1907), secretary of the Royal Society of London, to deliver the Croonian Lecture, ${ }^{10}$ a lecture given annually on a biological topic by a prestigious researcher responsible for some relevant discovery. In his lecture, delivered on 18 March 1894, Cajal also referred to the physiopsychological interpretations of his histological discoveries, possibly at the suggestion of his friend and colleague Albrecht von Kölliker (1817-1905), Professor of Anatomy at the University of Würzburg, who alerted him to the particular interest of British scientists in the physiology of the nervous system (Jones, 1994). In his speech, which was published in both French and Spanish, Cajal (1894a, 1894b) speculates on the possibility of a phenomenon of neuronal plasticity in the cerebral cortex, and relates it to the process of learning and the development of intellectual and artistic abilities and so on.

The basis of his hypotheses was the increase in the number of connections between the neurons of the cerebral cortex ('differentiation and abundance of the protoplasmic processes and quantity of collateral and terminal nervous branches'; Cajal, 1984b: 159). These are the pyramidal cells, which he again refers to as 'psychic cells' (Fig. 2) because of their fundamental role in the integrative circuits of the cerebral cortex, through so-called 'cerebral gymnastics', in other words, mental exercise. Cajal himself recognized that:

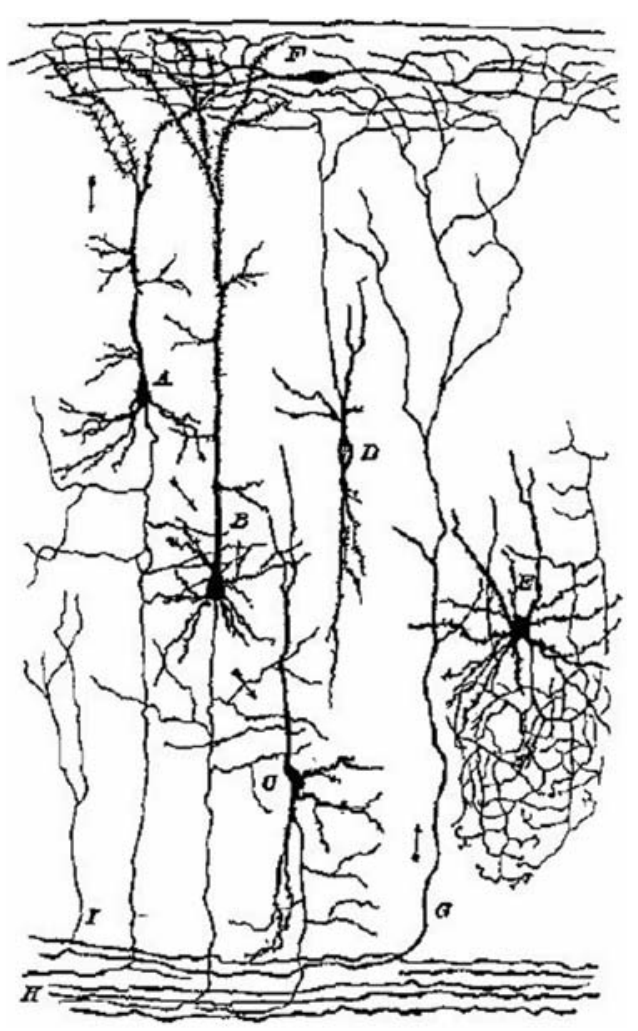

FIG. 2. One of the six figures used by Cajal to illustrate his Croonian Lecture. The arrows on the figure show the direction of the nervous impulse arriving at the cerebral cortex from the afferent fibres of the white matter $(G)$, passing first to the apical dendrites of the pyramidal cells, and then through the connections between cells via the horizontal collaterals of these pyramidal cells, which he called 'psychic cells' (source: Cajal, 1894a: 462) 
this anatomic-physiological hypothesis is not in principle original, since there are plenty of physiologists and psychologists who have sought the somatic characteristic of intelligence in the richness of cellular associations, but what is new is that it is founded on positive facts of structure, rather than on pure suppositions about functionalism and relationships between nerve corpuscles. (p. 159)

But despite his quite visionary thesis, the conclusion of the Croonian Lecture seems rather speculative for a person as prudent as Cajal: '... it is quite probable that ... the pyramidal cells have an entirely particular intraprotoplasmic structure, perfected in superior intelligences, a structure that would not exist in the corpuscles of the spinal cord or the ganglia' (p.160).

Both in this and in subsequent works, Cajal $(1894 a, 1895 a)$ describes, in support of his hypothesis, how animals lower down the phylogenetic scale lack the giant pyramidal cells typical of the higher animals, and how the connections are made only between neighbouring cells, while in the more evolved animals the connections run into thousands, and contact is made with neurons located in different regions, linking the cortex with the spinal cord. However, in contrast to the narrower reductionist postulates, Cajal (1895a: 497-9) proposed his law of 'avalanche conduction' or 'nervous avalanche', whereby:

all peripheral impressions, registered by the (sensitive or sensory) protoplasmic arborization of a single cell, would propagate in an avalanche towards the centres ... in other words, the number of neurons involved in the conduction grows progressively from the periphery towards the brain, in whose circumvolutions (tertiary sensory foci) resides the base of the conductive cone.

Thus, sensory impressions, for example, would constitute basic units or 'impression units' that would be registered in individual cortical cells, even though the sensory impressions would be registered by hundreds of cells and hundreds of times - cells which, moreover, would make hundreds of cortical connections. According to Cajal, one impression unit would be a 'simple movement registered, during sensory impression, by a single retinal cone or rod or by a ciliated cell of the cochlea' (p. 499).

These new Cajalian perspectives were closer to the psychological trend of associationism. Indeed, Cajal's neuronal theory provided a bridge between associationists and localizationists, especially when Cajal asserted that the 'impression unit' is stored in a neuron: 'we consider it likely that each group of pyramids, connected automatically to a sensory cell, conserves in a latent state various images, or rather, the impression units which that cell transmitted to it at various times' (p. 499; original italics). Thus, the sequence is clear: one unit, one neuron and each neuron connected to others so as to generate ideas by means of 'association fibers' (Køppe, 1983). 
This Cajalian relationship between neuron theory and the associationist postulates had a decisive influence on numerous scientists at the time, including Sigmund Freud (1856-1939) who in 1895 began work on a text that would eventually be published in 1950, entitled Entwurf einer Psychologie (Fig. 3). Freud supports the same ideas as Cajal on this subject, contributing the concepts of nervous energy (Cajal's 'impression units') and contact barrier (a kind of early, speculative approximation to the concept of synapse). With these two elements, Freud attempts to explain the phenomenon of memory as a gradual destruction of this barrier after successive nervous impulses, the resistance to subsequent sensory impressions decreasing with each new impulse ('memory traces'). However, as Køppe (1983) points out, Freud took a long time to position himself behind Cajal's neuron theory, and until 1895 supported the dynamic theory of representation, based on the reticularist perspectives of Camillo Golgi (1843-1926) and Joseph von Gerlach (1820-96): peripheral sensory impressions would be transmitted to the spinal cord but would not be stored, but rather represented 'as the alphabet exists in a poem' (Køppe, 1983: 9), being combined in units of higher category and interpreted in the cortex, not independently, but as combinations.
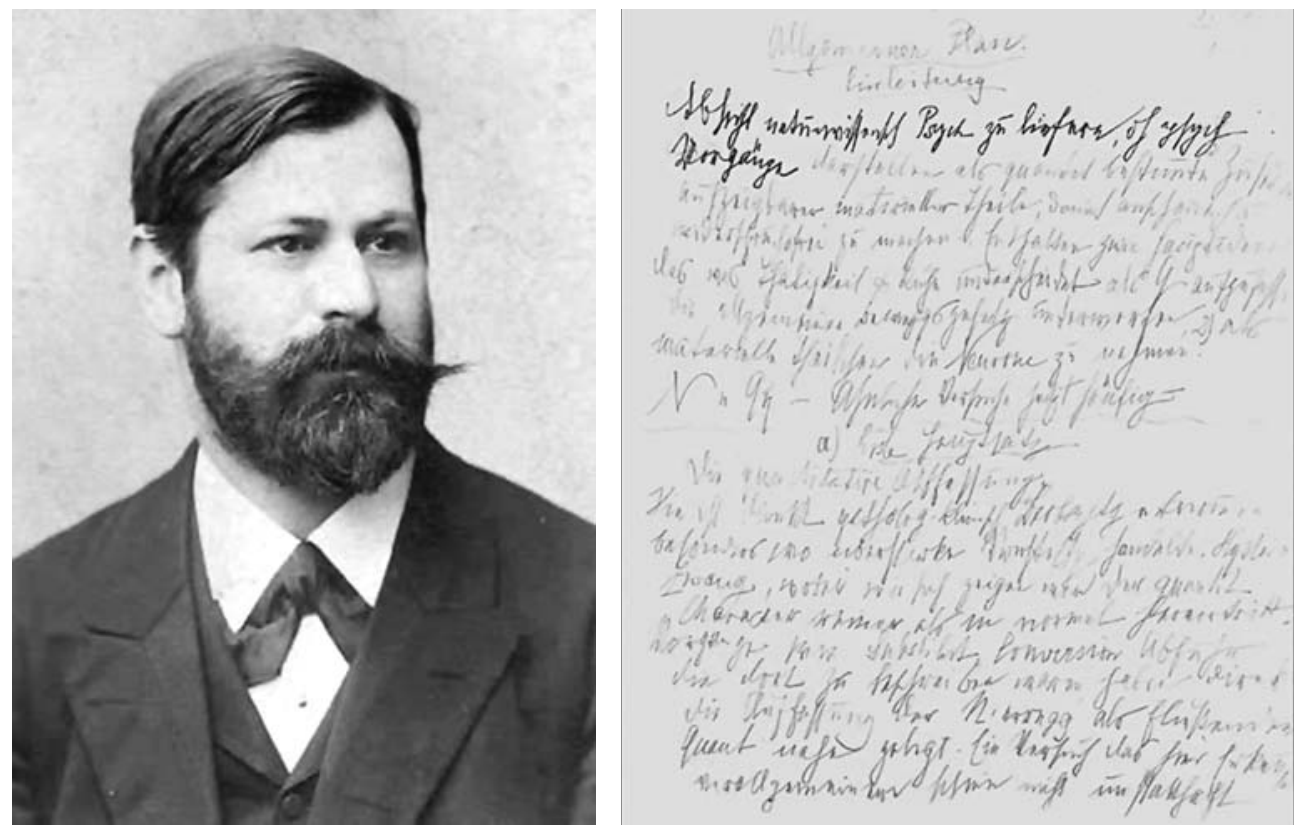

FIG. 3 Portrait of Sigmund Freud, from c.1895; on the right are his handwritten notes for his Entwurf einer Psychologie, in which he shared the postulates, supported by Cajal, on 'psychological neurophysiology'

(source: http://www.loc.gov/exhibits/freud) 


\section{On the channels of consciousness}

In 1896 Cajal published a scientific work devoted specifically to this psychophysiological field entitled Interpretaciones conjeturales sobre algunos puntos de histo-fisiología neurológica. He remarks that his discoveries on the histological structure of nerve centres (and those of other European histologists) had begun to be taken into account by psychologists 'with a view to throwing light on the mechanism of mental acts' (Cajal, 1896: 381). With regard to the question of why spinal cord cells produce movement and brain cells produce ideas, Cajal here supports the polyzoism hypothesis of Joseph Pierre Durand de Gros (1826-1901), according to which each nerve cell, regardless of its location, would be capable of reflecting a part of the stimulation coming from the outside world. 'The nervous system would consist, then, of innumerable consciousnesses, as many as there are cells', though there would be 'a cerebral one, superior, and with autocracy over all the rest' (p. 388). Thus, 'what we would call the self, or the person, would be none other than the cerebral consciousness, which is ignorant of - as it is exterior to - the conscious self of all the subordinate ganglionic individualities' (pp. 388-9; original italics).

Cajal's passion for these topics was so great in the 1890s that when he became a member of Spain's Royal Academy of Medicine in 1898 he considered giving his inaugural lecture on 'The physiologic-psychological inductions deriving from recent histological research'. Fortunately, he changed his mind as he thought the subject matter 'incomplete and premature', and opted for a purely histological topic (Valenciano, 1983). ${ }^{11}$ The text of this first proposition was never published, and is now considered lost. Likewise, in the first Spanish edition of his major work, Textura del sistema nervioso del hombre y de los vertebrados (1898-1904), he includes a brief chapter of a physiological nature on reflections about the mechanisms of thought, of consciousness, of sleep, and so on, a chapter he omitted from the French version, Histologie du systeme nerveux de l'homme et des vertebrés (1904, 1909), which is much more widely known internationally (Castilla del Pino, 1983).

\section{Summary: the dynamic factors of the substratum of the spirit}

After some years in which he did not address the problem of the neurobiological mechanisms of mental processes, Cajal returned to the subject in the foreword dated 22 April 1904 to a book, Introducción al Estudio de la Psicología Positiva (see Appendix C) by Tomás Maestre Pérez (1857-1936), Professor of Legal Medicine at the Faculty of Medicine in Madrid. In this text, Cajal associates greater intellectual development with the richness and quality of the neuronal associations in the brain. However, he hypothesizes on the intimate biological location (the 'material substrate') of the 'dynamic factor ... whose mission is to stimulate and sustain the combustion in the furnace of thought so as to forge ... higher concepts.' (Cajal, 1905: iii). The cellular source of this mysterious principle ('be it called soul, will, activity, energy or whatever'; p. iii) would lie, according to Cajal, in one of the two types of cells in the cerebral 
cortex, that is, 'the pyramids or long-axon cells, and the short-axon corpuscles' (p. iii). It would be the cerebral pyramids through which 'the train of thought runs', but the short-axon corpuscles (much more developed in the human brain than in that of lower animals) may also house part of this dynamic factor, insofar as their dendrites receive information from the associative and sensory pathways and transmit it to the long-axon neurons. These latter cells would act as 'energy condensers', which would lead, depending in the circumstances, to the principal pathways (Cajal, 1905).

Cajal also mentions here, as he did in his Croonian Lecture, the importance of proper upbringing and education and of external influences for the process of intellectual development:

interneural association, despite its hereditary nature, is liable to be influenced and disturbed in childhood and adolescence by education and habit; thus, it frequently occurs that a brain capable of attaining sophisticated organization is transformed into a mediocre organ due to the fact that such influences ... suspend or moderate the growth of the conductors responsible for logical association ... It is sad to see how these wretched slaves of the brain, shackled to tradition and routine by the subtle bonds of nervous fibre - a chain more effective than that of a convict since they wear it in their souls without perceiving it - ingenuously take liberty for justice, suggestion for truth; faith for reason; goodness for talent ... (Cajal, 1905: iii)

In spite of making such conjectures, Cajal is aware of the limitations for reliably clarifying these intimate mechanisms of mental processes, as well as the 'substratum of the spirit'; he writes:

all the efforts of brain histology to plough the land, to discover paths, to scour the darkest corners of the virgin neuronal jungle, will be in vain unless physiology can reveal to us the nature of the nervous wave, and the transformations it undergoes to generate the phenomena of memory, of impulsion and of awareness; unless it can explain to us how each sensation, each idea, each act of volition, apart from its representative content, impregnates the self with a specific emotional aura. (p. iv; original italics)

\section{And continues:}

As things stand today, it cannot be denied that objective psychology or mental histology or the nascent science, whose purpose is to subordinate the series of mental acts reflected in consciousness to a parallel series of physico-mental phenomena effected by cells, is still largely reduced to the quite primitive and speculative method of the physiological interpretation of the anatomical evidence ... the cerebral physiology of understanding and volition continues to constitute the great enigma ... The most important processes, namely, memory, association, awareness, logical operations, imagination, the entire emotional sphere - indeed, all the most intimate and crucial aspects of mental life - stay in the background. (pp. iv-v) 
Even so, Cajal's optimistic scientific spirit reappears at the end of the foreword:

But let us not despair. The task is a long one but the future of mankind is longer still. The abyss is a deep one, but to bridge it there are innumerable generations of wise scholars ... Let us trust in the resources of that admirable human brain which struggles to understand itself. In time, it shall become, because it has a will to do so, its own master and its own architect. (p. vi)

\section{Cajal and theories on sleep: the antithesis of Freud}

Cajal's interest in investigating the neurobiological mechanisms of sleep and dreams may constitute, as mentioned above, a projection of his research on hypnotism. In 1908 he published a paper on theories of dreams, Las teorias sobre el ensueño, ${ }^{12}$ which begins: 'Dreaming is one of the most interesting and most wondrous phenomena of brain physiology' (Cajal, 1908: 87). After a brief summary of the contributions from the most prestigious 'essayists in this field' (Marie de Manaceine, Henri Bergson, Alfred Maury, Yves Delage), Cajal focuses on the perceptions and visual hallucinations of dreams, using self-explorations (of which he says he has analysed thousands) obtained after autosuggestion the previous day. With regard to methodology, he argues that '.. given that when we dream, memory and voluntary activity are annulled or severely weakened' (p. 90), for the study of these phenomena it is necessary to concentrate on a phase of sleep 'during which the analytical self overcomes the dream, scrutinizing it and judging it' (p. 91; original italics) - that is, the phase just before waking. In order to analyse these visual images he proposes a kind of training (creation of a habit) by means of vigorous autosuggestion just before sleep. Although he admits that the success of this procedure is quite variable (once or twice out of a hundred, improvable with self-training), 'the exploratory programme is to carry out, enabling the study, during the final phase of dreams, of some of their principal attributes.' (pp. 91-92). Cajal calls this procedure 'the introspective method'.

Cajal gives examples of self-analysis of his dreams of the type 'I found myself in the middle of a dense forest', 'I dream that I'm walking along a street in Madrid', 'we dream that we are examining a book' (p. 92-96), dealing with the study of the colour, the perspective and the relief of the images in the dream, as well as the eye and head movements. His conclusions on self-experimentation through this method of introspection are as follows: (a) the visual hallucinations of dreams have the same relief as the sensations themselves; (b) the colour of visual hallucination can attain the same richness of tone as external reality; (c) the form of the mental projection undergoes great fluctuations during sleep; (d) the visual field of the dream is fixed, not varying in relation to eye or head movements; (e) the brilliance of the colours disappears before waking, fading to greyish tones; and ( $f$ ) the visualized objects may correspond not to real events, but rather to a heterogeneous mixture of many real sensory memories (Cajal, 1908). 
Concentrating in particular on the anatomical 'substractum' [sic] of these phenomena, Cajal asks himself: 'Do they arise in the associative, higher or projective centres?, Are the retina and the optic nerve involved?' (p. 90). His analyses of introspection eventually led him to decide that there was no retinal substrate. The definitive evidence came from experiments with 'people who went blind as adults; those who could populate their memory in the early years of their life with pictures dream with optical images, despite lacking both retina and optic nerve.' (p. 97).

Although he mentions setting out the neurophysiological theories on these phenomena ('as we shall see later', he writes), it appears that these explanations were to be given in a publication that never actually saw the light of day - the 1908 paper concludes: 'to be continued'; see Appendix B.

In addition to this paper and its proposed continuation, Cajal seems to have intended to publish a book on 'sleep and the phenomena of dreaming', but he never did so, despite the numerous data recorded in a manuscript that was also lost during the Civil War. Nevertheless, some of his ideas on the subject were preserved thanks to the 1908 paper, his correspondence and, above all, an interesting foreword he dedicated to a work of poetry by the writer Marcos Zapata (1844-1914), even though it was published six years earlier, in 1902 (Appendix C). In this letter-foreword, Cajal attempts to provide a neuro-physiopsychological explanation of dreams:

Everyone will have noticed that when we sleep, the ideas and events in the special world that unfolds before us are usually (and there are exceptions that if we think about it actually prove the rule) totally unconnected with the thoughts that preoccupy us and with our everyday tasks and demands. If we analyse dreams carefully, we see that they often involve scenes from our childhood or youth, rarely remembered, or capriciously fragmented and absurdly combined images, whose sensory elements and residues have not been refreshed for a long time, so that they remain outside the field of consciousness ... We can deduce from this that when we sleep we do not rest completely, but rather that part of the brain that became weary while we were awake; the fallow lands of the brain, that is, the cells in which unconscious images are recorded, stay awake and become excited, rejuvenating themselves with the exercise they did behind the back of the conscious mind ... Through such gymnastics, these extraordinary contingents, a kind of reserve of ideas, attain the condition for rapid mobilization when the various demands of wakeful work and the unforeseen exigencies of fight require them. And since many daytime brain operations activate and tire out groups of cells scattered throughout the brain, especially those responsible for the highest of mental activities, that is, the critical faculty, constantly alert to the acts of speaking and listening, the majority of dreams consist of scraps of ideas, unconnected or weirdly assembled, somewhat like an absurd monster without proportions, harmony or reason. (Cajal, 1902; reproduced in Durán and Alonso, 1960: 164-5) 
Cajal was in the habit of noting down the content and course of both his own dreams and those of other people, in an effort to interpret their meaning. He also studied the different theories on the matter, so fashionable at the time, and especially the ideas of Sigmund Freud, with which he disagreed openly, although his way of expressing this disagreement was at times perhaps somewhat superficial or trivial for an eminent scientist. Indeed, in a letter to his friend Gregorio Marañón (1887-1960), Cajal writes, in relation to Freud's approach to dreams:

... I consider as collective lies both psychoanalysis and Freud's theory of dreams; nearly all the findings of the wise Viennese scholar can be explained by individual or collective suggestion. Of this I shall speak if I manage to live long enough to write another book on dreams, in which I summarize thousands of self-observations contradicting Freud's theory. (Durán and Alonso, 1960: 165; see also Elguero, 2004)

Moreover, in another letter, ${ }^{13}$ he returns to the matter:

I find I must refer to Freud and criticize some of his more daring assertions. Why, in more than five hundred dreams I have analysed (without counting those of people I know), is it impossible to verify, except in extremely rare cases, the doctrines of the surly and somewhat egotistical Viennese author, who has always seemed to me more preoccupied with the idea of founding a sensational theory than with the desire to serve austerely the cause of scientific theory. (Durán and Alonso, 1960: 165-6)

Apart from the letters, Durán and Alonso (1960) also reproduced some notes Cajal wrote on the pages of Freud's books in his library, for example: '... the interpretation is so subtle (in the forgetting of verses, words and phrases) that it is impossible to believe the author' (p. 166). Even in his final memoirs, El mundo visto a los ochenta años, published in 1934, the year of his death, Cajal continued to express his disagreement with Freud on this issue. We agree with the opinion of Ibarz (1994) and Elguero (2004) who argue that these differences between the two scientists in the interpretation of sleep-related phenomena were nothing more than the extension of their methodological approaches: a purely physical interpretation in the case of Cajal and a mental one in the case of Freud. Moreover, with the passage of time, and as Freud became a widely recognized figure in the field of psychiatry, Cajal would never succeed in understanding his innovative theories.

Despite Cajal's great interest in discovering the intimate neurohistological mechanisms of dreams, the task must have seemed to him an impossible one. This emerges from the remarks he made in a letter to his friend and disciple, the Augustine priest Zacarías Martínez Núñez (1864-1933): ${ }^{14}$

it would not be of much interest to you what histologists imagine to give a physio-chemical or cytological explanation to sleep. The fact is that nobody 
is really sure about the matter... Truly, the nervous machinery is so complex, and its delicate anatomy still conceals so many mysteries, that just now it would be quite rash to attribute sleep to a known histological factor, when it may well be that some other, unknown aspect is involved ... (Durán and Alonso, 1960: 164)

\section{From enthusiasm to self-criticism: Cajal's period of reflection on his psychological theories}

In 1906 Cajal was awarded the Nobel prize for his histological work, so he may have decided to concentrate his research on this field to the detriment of all others (such as psychology). Perhaps, too, his interest in psychological matters also began to decline because, in contrast to the reliable facts verified in his morphological publications, his psychophysiological postulates always remained in the realm of conjecture and speculative hypotheses. It was for this reason that he embarked on a period of self-criticism in relation to this aspect of his previous scientific activity, which may indeed have contributed to the fact that his work in the field of psychology has gone largely unnoticed and ignored until recently (Elguero, 2004; Ibarz, 1994).

In this regard, it can also be noted that Cajal even felt the need to withdraw the neurobiological account of mentation that he had developed earlier in his career. In 1895 he had published his paper, Algunas conjeturas sobre el mecanismo anatómico de la ideación, asociación y atención (also published in German; see Appendix A), and some of his conclusions have already been discussed above. He set out to explain the intimate mechanism of certain mental acts - such as attention, association of ideas, sleep and wakefulness - through morphological changes in the neuroglial cells of the grey matter, which would act as an electrical commutator of the nervous currents. According to Cajal (1895: 506):

during the state of relaxation, the neuroglial appendices ... would penetrate between the nervous arborizations and the cells or their protoplasmic appendices, as a result of which the passage of the currents would become suspended or severely hindered. This explains mental repose and sleep, be it natural or induced (by narcotics or by hypnotism) ... During the state of contraction, the pseudopods would contract, absorbing, as it were, the protoplasm of the secondary appendices, so that previously separated cells and nerve arborizations came into contact. Via this mechanism the brain would pass from a state of repose to one of activity.

Likewise, implicating the perivascular neuroglia, he develops a theory of attention:

Under the influence of the will, the fixed pseudopods in the capillaries of a more or less considerable group of perivascular neuroglial cells would contract, and the capillary, stretched in all directions towards the adjacent grey matter, would increase its diameter and occupy nearly all the 
lymphatic cavity surrounding it. This would permit congestions of the grey matter as precise and restricted as required by the monoideism of attention. (pp. 507-8; original italics)

However, nearly 30 years later, he wrote that 'in all those extremely speculative ramblings one can detect the presence, quite true to her nature, of the madwoman of the house' (Cajal, 1923: 290). Nevertheless, in the Spaniard's defence, it should be stressed that in the 1890 s there was a scientific view quite prone to these types of interpretation. Thus, some pathologists, for example Jacques-Raphaël Lépine (1840-1919), tried to explain the morphological basis of states of hypnosis and absentmindedness, and psychiatrists, such as Eugenio Tanzi (1856-1934) and Ernesto Lugaro (1870-1940), that for hallucinations and other psychological processes. Even Mathias Duval (1844-1907) attempted to account for sleep-wakefulness variations through the ameboid retraction of the expansions and arborizations of nerve cells in different phases of conscious or unconscious functional activity. Thus, during sleep (natural or induced by narcotics), the nervous ramifications would retract, interrupting the passage of the nervous current, while in the state of being awake the opposite would occur (Duval, 1895). These postulates are refuted at several points by Cajal (1895), who proposes as an alternative the somewhat bizarre hypothesis of the neuroglial cells.

The passage of time and incipient morphological discoveries led Cajal to retract his bold claims, and he affirmed definitively that the participation of the neuroglia in the mental acts of attention and association of ideas was:

a frankly inadmissible conjecture ... Moreover, the processes of attention, association of ideas, emotion, intellectual phenomena, etc., are so enormously complex and so enigmatic today, from the histological, histochemical and energetic perspectives, that all research carried out in this direction would appear quite audacious ... Centuries, perhaps thousands of years, will pass before man is able to catch a glimpse of the unfathomable mystery of the mechanism, not just of our own psychology, but even of that of the simplest insect. (Cajal, 1923: 290-1)

\section{Epilogue}

Leaving aside his sporadic incursions into the histopathological study of the brains of patients with mental disorders, such as schizophrenia, the two topics within the psychiatric/psychological sphere that most attracted Cajal throughout his life were undoubtedly the mechanisms of sleep, in the interpretation of which he openly disagreed with Freud, and the relations between nervous centres and mental processes, chiefly with regard to their biological basis. Indeed, Cajal went so far as to use the term 'psychic cells' to denote the pyramids of the cerebral cortex. However, this question - a highly fashionable one around the turn of the last century due to the influence of the positivist and associationist 
bio-philosophical schools - was of such a nature that Cajal, despite having put forward some interpretive hypotheses, considered it excessively prone to erroneous, speculative and fanciful explanations. In response to the question of whether the supreme phenomenon of consciousness has its substrate in all the brain cells or exclusively those of association, Cajal (1896: 392) concluded:

We are not impatient to contemplate the grand edifice [of the intimate functioning of nervous centres] in all its finished glory. The supreme synthesis will come only much later, when all the material has been gathered, and when neither the chemistry nor the structure of the nerve cells hold any more secrets for us.

More than a century later, these prudent words still have the ring of truth.

\section{Notes}

1. But the historical importance of the debate that emerged on the subject of hysteria and hypnotism lay in its influence on a young man who attended Charcot's lectures, Sigmund Freud (1856-1939), who together with Josef Breuer (1842-1925) published Studien über Hysterie in 1895, and began studying the therapeutic effects of the techniques of suggestion and hypnosis, eventually developing his method of Freie Assoziation. The culmination of this work, in 1898, was his defining achievement: the postulate of psychoanalysis. However, Freud's theories would never be well received by Cajal.

2. Various authors from Valencia also joined in this discussion, including Faustino Barberá (1850-1924), who in his publications aligned himself with Bernheim's line of thought.

3. It suffices to mention, with Diéguez and Diéguez (2002), the Englishman Frederic Myers (1843-1901), the Swiss Théodore Flournoy (1854-1909), the French Nobel laureate Charles R. Richet (1850-1935) and the German Wilhelm M. Wundt (1832-1920), considered to be the founder of experimental psychology.

4. It was during this visit that Simarro showed Cajal Golgi's silver nitrate method (his famous reazione nera), so crucial for his future histological career (Cajal, 1923).

5. Similar to those organized in other countries at this time, such as the Society for Psychical Research, founded in 1882 by English and American doctors.

6. This hypothesis is more than plausible, since Cajal could hardly have carried out such an act of obstetrics with a stranger, given his minimal experience as a clinical physician.

7. Bernheim, in his De la suggestion et de ses applications à la thérapeutique (1886), does not mention this aspect, though he does dedicate a chapter to various disorders, including menstrual problems.

8. The following year, this article was translated into German and published in a prestigious German journal.

9. Today, we know that these prefrontal cortex cells form part of an area closely linked to the executive functions of the brain (Goldman-Rakic, 2002), above all certain cognitive functions such as memory, so that Cajal's proposal was indeed largely correct.

10. The Croonian Lecture was established in honour of the seventeenth-century English physician William Croone (1633-86).

11. Nevertheless, in the introduction to his new speech, he mentioned that his original idea 'referred to the incongruences and maladaptations of man in the moral, intellectual and physical spheres' (Elguero, 2004: 20). 
12. This work appears to be the first in a series of articles which, due to diverse circumstances, was not continued.

13. Cajal's letter replies to one from Juan Paulis, in relation to Freudian subjects; published originally by Paulis, 1935.

14. The priest and biologist Zacarías Martínez would become Bishop of Huesca and Vitoria and Archbishop of Santiago de Compostela.

\section{Appendix: Works by Cajal}

Works on psychological and/or psychiatric subjects are listed in parts A, B and C; two general textbooks and two memoirs are given in part D.

\section{A. Publications}

(1889) Dolores del parto considerablemente atenuados por la sugestión hipnótica. Gaceta Médica Catalana, 12, 484-6.

(1892) El nuevo concepto de la histología de los centros nerviosos. Revista de Ciencias Médicas de Barcelona, 18, 457-76.

(1893) Neue Darstellung vom histologischen Bau des Centralnervensystems. Archiv für Anatomie und Entwicklungsgeschichte: Anatomische Abteilungen des Archiv für Anatomie und Physiologie, 17, 319-428.

(1894a) La fine structure des centres nerveux (The Croonian Lecture). Proceedings of the Royal Society London, 55, 444-67.

(1894b) Estructura íntima de los centros nerviosos. Revista de Ciencias Médicas de Barcelona, 20, 145-60.

(1895a) Algunas conjeturas sobre el mecanismo anatómico de la ideación, asociación y atención. Revista de Medicina y Cirugía Prácticas, 36, 497-508.

(1895b) Einige Hypothesen über den anatomischen Mechanismus der Ideenbildung, der Association und der Aufmerksamkeit. Archiv für Anatomie und Entwicklungsgeschichte: Anatomische Abteilungen des Archiv für Anatomie und Physiologie, 19, 367-78.

(1896) Interpretaciones conjeturales sobre algunos puntos de histo-fisiología neurológica. Biblioteca de la Ciencia Moderna, 379-92.

(1908) Las teorías sobre el ensueño. Revista Cajal de Medicina y Cirugía de la Facultad de Madrid, 3 (14/15), 87-98.

\section{B. Manuscripts known to have been finished before Cajal's death, but since lost}

Ensayos sobre el hipnotismo, el espiritismo y la metapsíquica.

Los ensueños: críticas de las doctrinas explicativas de los mismos.

Los sueños (continuation of the work published in the Revista Cajal de Medicina y Cirugia in 1908).

\section{Forewords to books by other authors}

(1902) Prólogo. In Marcos Zapata, Poesías (Madrid: Librería de Fernando Fé).

(1905) Prólogo (22 April 1904). In Tomás Maestre, Introducción al estudio de la psicología positiva (Madrid: Librería-Editorial Bailly-Baillière e Hijos), i-vi.

(1907) Prólogo. In Zacarías Martínez Núñez, Estudios Biológicos: La herencia. Hipótesis acerca del sueño. Optimismo científico (Madrid: Sáenz de Jubera Hermanos).

(1924) Prólogo. In Eugen Bleuler (translation by José María Villaverde), Tratado de Psiquiatría (Madrid: Calpe). 
D. Textbooks and memoirs referred to in the text

(1898-1904) Textura del sistema nervioso del hombre y de los vertebrados (Madrid: Imprenta y Librería de Nicolás Moya).

(1904, 1909) Histologie du système nerveux de l'homme et des vertebrés, Vol. 1, 1909; Vol. 2, 1904 (Paris: A. Maloine).

(1923) Recuerdos de mi vida. Historia de mi labor científica, 3rd edn (Madrid: Imprenta de Juan Pueyo).

(1934) El mundo visto a los ochenta años. Impresiones de un arteriosclerótico, 2nd edn (Madrid: Librería Beltrán, Tipografía Artística).

\section{References}

(Works by Cajal are given in the Appendix above.)

Albarracín, A. (1972) Intrusos, charlatanes, secretistas y curanderos. Asclepio, 24, 323-66.

Bernheim, H. (1886) De la suggestion et de ses applications à la thérapeutique (Paris: Octave Doin).

Castilla del Pino, C. (1983) Cajal y la sociología de la ciencia en España. Arbor, 447, $67-76$.

Charcot, J. M. (1882) Sur les divers états nerveux déterminés par l'hypnotisation des hystériques. Comptes-Rendus Hebdomadaires des Séances de l'Académie des Sciences, 94, 403-5.

Diéguez, J. and Diéguez, A. (2002) Sobre la introducción del hipnotismo en España: la recepción de los planteamientos de las escuelas francesas. Cuadernos de Psiquiatría Comunitaria, 2, 107-23.

Diéguez, A., Campos, R. and Huertas, R. (2006) Breve historia de la psiquiatría. In F. LópezMuñoz and C. Alamo (eds), Historia de la psicofarmacología. Vol. 1, De los orígenes a la medicina científica: sobre los pilares biológicos del nacimiento de la psicofarmacología (Madrid: Editorial Médica Panamericana, S.A.), 3-35.

Durán, G. and Alonso, F. (1960) Cajal. Vol. 1, Vida y obra (Zaragoza: Institución 'Fernando El Católico').

Durán, G. and Alonso, F. (1983) Cajal. Escritos inéditos, 2nd edn (Barcelona: Editorial Científico-Médica).

Duval, M. (1895) Hypothèse sur la physiologie des centres nerveux: Théorie histologique du sommeil. Comptes Rendus de la Société de Biologie de Paris, 2, 74-113.

Elguero, J. (2004) Metodología de la investigación: los ejemplos de Freud y de Cajal (Discurso de Recepción como Académico de Número) (Madrid: Real Academia de Ciencias Exactas, Físicas y Naturales).

Ellenberger, H. F. (1976) El descubrimiento del inconsciente. Historia y evolución de la psicología dinámica (Madrid: Gredos).

Freud, S. (1950) Entwurf einer Psychologie. In M. Bonaparte, A. Freud and E. Kris (eds), Aus der Anfängen der Psychoanalyse (London: Imago Publishing Co.), 371-466.

Gauld, A. (1992) A History of Hypnotism (Cambridge: Cambridge University Press).

Goldman-Rakic, P. S. (2002) The 'psychic cell' of Ramón y Cajal. Progress in Brain Research, 136, 427-34.

González, H., Cano, A. J. and Miguel-Tobal, J. J. (1995) El hipnotismo en España durante el siglo XIX: una visión histórica a través de sus protagonistas. Revista de Historia de la Psicologia, 16, 203-16.

Ibarz, V. (1994) La psicología en la obra de Santiago Ramón y Cajal (Zaragoza: Institución 'Fernando El Católico'). 
Jones, E. G. (1994) Santiago Ramón y Cajal and the Croonian Lecture, March 1894. Trends in Neuroscience, 17, 190-2.

Køppe, S. (1983) The psychology of the neuron: Freud, Cajal and Golgi. Scandinavian fournal of Psychology, 24, 1-12.

López-Ibor, J. J. and Fuentenebro, F. (2006) Historia de la psicopatología en España. In F. López-Muñoz and C. Alamo (eds), Historia de la psicofarmacología. Vol. 3, La consolidación de la psicofarmacología como disciplina científica: aspectos ético-legales y perspectivas de futuro (Madrid: Editorial Médica Panamericana, S.A.), 1881-909.

López-Muñoz, F., Carbonell, A. L. and Boya, J. (1998) Aproximación a la producción científica de Cajal desde una perspectiva bibliométrica. Archivos de Neurobiología, 61, $41-66$.

Paulis, J. (1935) Cajal (Barcelona: Publicaciones Andrómaco).

Timoner, G., Nicolau, M. C., Gamundí, A. and Rial, R. V. (1995) La psicología sugestiva en Ramón y Cajal. Revista de Historia de la Psicología, 16, 225-32.

Valenciano, L. (1983) Cajal (recuerdos y reflexiones de uno de sus últimos alumnos). Archivos de Neurobiología, 46, 272-81.

Youssef, I. and Schorer, C. E. (1996) Ramón y Cajal and hypnosis. Proceedings of the Xth World Congress of Psychiatry, August 23-28, Madrid (Madrid: The World Psychiatric Association), 210. 